\title{
Anne Delchiaro et François Pernot, Jeanne d'Arc «La Pucelle»
}

\section{Sophie Mentzel}

\section{Q OpenEdition}

1 Journals

\section{Édition électronique}

URL : http://journals.openedition.org/studifrancesi/5355

DOI : 10.4000/studifrancesi.5355

ISSN : 2421-5856

Éditeur

Rosenberg \& Sellier

\section{Édition imprimée}

Date de publication : 1 décembre 2016

Pagination : 535

ISSN : 0039-2944

\section{Référence électronique}

Sophie Mentzel, « Anne Delchiaro et François Pernot, Jeanne d'Arc «La Pucelle» », Studi Francesi [En ligne], 180 (LX | III) | 2016, mis en ligne le 01 janvier 2017, consulté le 18 septembre 2020. URL : http:// journals.openedition.org/studifrancesi/5355 ; DOI : https://doi.org/10.4000/studifrancesi.5355

Ce document a été généré automatiquement le 18 septembre 2020.

\section{(c) (i) (9)}

Studi Francesi è distribuita con Licenza Creative Commons Attribuzione - Non commerciale - Non opere derivate 4.0 Internazionale. 


\title{
Anne Delchiaro et François Pernot, Jeanne d'Arc «La Pucelle»
}

\author{
Sophie Mentzel
}

\section{RÉFÉRENCE}

ANNE DELCHIARO et FRANÇOIS PERNOT, Jeanne d'Arc «La Pucelle», Paris, Honoré Champion, 2015, «Champion L'Histoire», 143 pp.

1 La collection «Champion l'Histoire» a pour but de faire découvrir ou redécouvrir aux amateurs éclairés d'Histoire, dates et personnages centraux de la mémoire collective. C'est dans cet esprit de très large diffusion que l'ouvrage sur Jeanne d'Arc est signé par ses deux auteurs: François Pernot, l'un des directeurs de la collection et professeur à l'université de Cergy-Pontoise, écrit des livres d'histoire pour les adultes et les enfants; Anne Delchiaro travaille dans l'édition pour des publics de tous âges. "Faire rêver» jeunes et moins jeunes à travers l'Histoire, tel est leur souhait, affiché en exergue.

2 Dans ce but, le livre emprunte deux directions qui s'entrecroisent avec bonheur: il s'agit de familiariser les lecteurs avec Jeanne, que l'on approche à travers divers témoignages contemporains, et dont on suit le trajet de Domrémy au bûcher de Rouen. Il s'agit aussi de montrer comment s'est construit le mythe dans toute sa diversité: icône chrétienne, républicaine, royaliste, toile où se projettent toutes les visions de la France, La Pucelle fait dire à Maurice Barrès, cité dans l'ouvrage, que «tous les partis peuvent se réclamer de Jeanne d'Arc. Mais elle les dépasse tous. Nul ne peut la confisquer».

3 C'est pourquoi le récit chronologique de l'histoire de Jeanne, riche et détaillé, s'agrémente d'une iconographie largement empruntée aux livres d'Histoire des siècles passés: les manuels scolaires des $\mathrm{XIX}^{\mathrm{e}}$ et $\mathrm{XX}^{\mathrm{e}}$ siècles représentent tantôt la vierge inspirée par Dieu, tantôt la combattante au service de la Nation. Autant de visages de Jeanne d'Arc, dont les auteurs ont su rendre la simplicité et la complexité, à travers un 
ouvrage agréable à lire dans lequel l'Histoire, pétrie de romanesque, parvient, en effet, à «faire rêver». 